\title{
A CÍMADÁS PROBLEMATIKÁJA ÉS A TUDOMÁNYOS SZÖVEGALKOTÁS OKTATÁSA AZ IPOO-MODELL ALAPJÁN
}

\section{Szerző:}

\author{
Rási Szilvia (Drs) \\ Eszterházy Károly Egyetem
}

Szerző e-mail címe:

szilviarasi@gmail.com

\section{Lektorok:}

Domonkosi Ágnes (PhD)

Eszterházy Károly Egyetem

Mező Katalin (PhD)

Debreceni Egyetem

...és további két anonim lektor

\begin{abstract}
Absztrakt
Az utóbbi időben a tudományos írás (academic writing) mint kutatási terület, téma egyre nagyobb szerepet kap a nyelvészeti tudományos diskurzusban, különösen nemzetközi színtereken. Mindazonáltal a tudományos írás szerves részét képező címadással mind nemzetközi, mind hazai viszonylatban csekélyebb számú tanulmány jelent meg. A jelenlegi kutatás a magyarországi szakirodalmat kívánja bővíteni. A tanulmány egy olyan kísérlet tanulságait mutatja be, amelynek során két absztrakthoz egyetemi oktatóknak és hallgatóknak kellett címet rendelni. A vizsgálat az absztraktok címének nyelvi megalkotottságát, sajátosságait vizsgálja és azt kívánja bemutatni.

Jelen tanulmány két fő részből áll: az első az elméleti rész, a második a vizsgálat során összegyűjtött és rendszerezett adatokat mutatja be. A gyakorlati rész a konkrét kutatást mutatja be, aminek mintájában 107 adatközlő vett részt. Az adatokat kérdőíves vizsgálat segítségével gyűjtöttük össze. Az eredményekből egyértelműen látszik, hogy a tanár szakos hallgatóknak nagyon kevés a tudományos írással kapcsolatos tapasztalatuk, ezért mindenképp megfontolandó, hogy egy IPOO-modellre épített tudományos szövegalkotás kurzus belekerüljön a hallgatók képzési programjába.
\end{abstract}

Kulcsszavak: tudományos írás, cím, hallgatók

Diszciplinák: pedagógia, nyelvészet

\begin{abstract}
THE PROBLEM OF TITLES IN STUDENTS' WRITTEN WORKS AND TE ACHING OF ACADEMIC WRITING BASED ON THE IPOO-MODELL

In recent times academic writing - as a research area and topic - has become popular in scientific discourse, especially in the international literature. However, there is a
\end{abstract}


smaller amount of studies which concern the problem of giving titles. Our work intends to join the latter, and aims to research the role of titles in academic writing. In this paper we present the conclusion of an experiment in which university teachers and university students had to give title to two given abstracts. The study examines the form and characteristics of the titles given to the specific abstract.

The current paper consists of two main parts: the first is the theoretical and the second is the practical part of our research. The practical part introduces the research, in which 107 university students have been participated. The data was collected using the questionnaire method. The results clearly show that teacher trainees do not have much academic writing experience, therefore, it is important to consider to include an Academic writing course based on the IPOO-modell into the students' training program.

Keywords: academic writing, titles, students

Disciplines: pedagogy, linguistics

Rási Szilvia (2019): A címadás problematikája és a tudományos szövegalkotás oktatása az IPOO-modell alapján. OxIPO - interdiszciplináris tudományos folyóirat, 2019/3, 25-38. doi: 10.35405/OXIPO.2019.3.25

Míg az angolszász kutatásokban és felsőoktatásban a tudományos szövegalkotásnak és azok kutatásának komoly figyelmet szentelnek (Al-Khasawneh, 2017; Cross és Oppenheim, 2006; Talebzadeh és tsai, 2013), addig hazánkban az egyetemek képzési programjaiban írásmódszertani kurzust csak elvétve találunk, illetve az ezzel foglalkozó kutatások (Veszelszki, 2016, 2018) száma is csekély. Mindazonáltal elvárásnak számít az, hogy a hallgatók tudományos igénnyel megszerkesztett, megfogalmazott munkákat (például tanulmány, beadandó, szakdolgo- zat) nyújtsanak be tanulmányaik során. Joggal vetődik fel tehát az igény, hogy kerüljön be a hallgatók képzési programjába egy tudományos szövegalkotás kurzus, amely nagy segítséget nyújtana a hallgatóknak a tudományos munkáik megírásakor.

Jelen tanulmány egy, a címadás problematikájával foglalkozó kutatás eredményeit ismerteti, amely rámutat a tanárszakos hallgatók címadással kapcsolatos hiányosságaira. A munka elméleti része három fő szakaszból állt. Az első bemutatja a címeket a funkciójuk szerint, majd részletezi az 
egyes címtípusokat. Ebben a részben röviden ismertetésre kerül a diskurzushibridizáció jelensége is. Az ezt követő rész kitért az academic writing fogalmára. A harmadik szakasz felvázolja az IPOOtanulási modellt és részletezi a produktív-, reproduktív, és improduktív tanulást is. A következőkben ismertetésre kerül a kutatás hipotézise, illetve a vizsgálat során alkalmazott módszer. Ezt követi majd az adatok rendszerezése, illetve az IPOOmodellre épített tudományos írást segítő kurzus felvázolása és ennek hatása a címadásra.

\section{A cím}

A cím nem más, mint egy szöveg címkéje, amit az olvasó elsóként olvas el a szöveggel való érintkezés során. A címnek az egyik legfontosabb feladata az, hogy ráirányítsa a figyelmet a szövegre, kiemelje annak lényegét, valamint szemléltesse a szerző értékrendjét is (Tolcsvai, 2001; Szikszainé, 1999; Domonkosi, 2016; Tomesz, 2009, 2015; Day, 1995; Falus, 2004; Kemény, 1985). Robert A. Day szerint egy rosszul megfogalmazott cím során a szerző olvasókat veszíthet el és/vagy sosem jut el a szövege a célközönséghez (Day, 1995). Ennek alapján tehát fontos, hogy a cím figyelemfelkeltő legyen. Szikszainé (1999) a címadás legnyilvánvalóbb céljának az azonosítást, leltározás elősegítését és a figyelemfelkeltést határozza meg. Ez pedig egyértelmúen alátámasztja azt, hogy a cím egyik legfőbb feladata az olvasó figyelmének felkeltése.
Tolcsvai a címnek két párhuzamosan érvényesülő funkcióját említi meg, ezek a:

a) metatextuális funkció: ez esetben a cím nem a szöveg tartalmára, hanem a szövegre mint egészre utal;

b) tartalmi funkció: itt a cím utal a szöveg tartalmára (Tolcsvai, 2001).

E két funkció jelenléte rámutat a cím összetettségére, vagyis, míg a metatextuális funkció kívülrôl láttatja a szöveget, addig a tartalmi funkció belülről utal a szöveg tartalmára. Továbbá, a cím és a szöveg viszonya lehet deiktikus, ami azt jelenti, hogy a cím rámutat a szövegre, illetve metonimikus, amikor maga a cím képviseli a szöveget (Tolcsvai, 2001). Szikszainé (1999) megjelöli a cím kataforikus szerepét is, vagyis a cím további feladata (a figyelemfelkeltés mellett), hogy előinformálja az olvasót az írásról.

Kemény Gábor kétféle címtipológiájában (Kemény, 1985) stilisztikai és szövegszerveződési szempontokat érvényesülnek. A felosztásában nem a cím nyelvi formája volt a mérvadó, hanem az alapján ele-mezte a sajtócímeket, hogy azok milyen módon kapcsolódnak a szöveg nyitó és/vagy záró helyzetű motívumaihoz. Ez alapján négy csoportot alkotott:

1. nyitás $=$ cím. Az ilyen címek esetében a szöveg jellemzően a címben felvetett ötletet folytatja.

2. zárás = cím. Ezek a címek a szöveg utolsó mozzanataira, a befejezésre utalnak.

3. nyitás $=$ zárás $\neq$ a cím. Ezekben az esetekben a címben nincs utalás sem a nyitás- 
ra, sem a befejezésre, viszont a szöveg elején és zárásában ugyanaz a kép van.

4. nyitás $=$ qárás $=$ cím. Ebben az esetben a nyitó- és zárórész, valamint a szöveg címe megegyezik.

Szikszainé (1999) a címeket funkciójuk alapján négy csoportba sorolhatja:

- témamegjelölő cím,

- címkeszerepú cím,

- reklámszerepú cím,

- múfajjelölő cím.

A témamegjelölő cím egyértelműen utal a szöveg tartalmára, egyértelműen következtetni lehet belőle arra, hogy miről írt a szerző. A címkeszerepű címre a rövidség jellemző. Ezek általában egy-, kétszavas címek, melyek nagyon gyakran erős hangulatkeltő jelleggel bírnak. A reklámszerepú cím feladata a figyelemfelkeltés, hatásvadászat. Leggyakrabban a publicisztika alkalmazza. A műfajmegjelölő címekből a cím műfaja azonnal kiderül, bár nagyon sokszor a múfaj határozza meg a címet (Szikszainé, 1999).

$\mathrm{Az}$ eddig felsorolt címtípusokat egy olyan modellben írjuk le, melyben a figyelemfelkeltés skálája és az informativitás skálája szemlélteti az előbb felsorolt funkciókat. A tudományos szövegek címei az informativitás skáláján helyezkednek el. Az utóbbi időkben viszont a tudományos szövegek címei (is) elmozdulnak az figyelemfelkeltés, az média nyelvhasználata irányába, vagyis a tudományos nyelv hibridizálódik. Ezt nevezzük diskurzushibridizációnak (Fairclough 1992, 1993).

Terjedelmét tekintve, ha túl hosszú egy cím, fennáll a veszélye annak, hogy fölös- leges szavakat tartalmaz. Amennyiben túl rövid, feltételezhető, hogy nem fedi le megfelelően a szöveg tartalmát (Day, 1995). V. Rodrigues (2013) szerkesztő tanácsa, hogy egy tudományos beszámoló, tudományos kutatásról írt tanulmány (research paper) címe ne legyen hosszabb, mint 10-12 szó. A magyar szakirodalomban a tudományos szövegek bizonyos résztípusai esetében (például pedagógiai kutatás) Falus (2004) a cím terjedelmének felső határaként 12-15 szót ad meg. Úgy véli, ha a szerző alapos címet szeretne adni, akkor a címnek tartalmaznia kell a függő- és független változókat, azok kapcsolatát, illetve a populáció jellemzőit is.

\section{Academic writing}

Magyarországi viszonylatban jellemző, hogy az anyanyelvi tantárgyak esetében (a tanárok és tanárjelöltek) kevésbé nagy hangsúlyt fektetnek általában a nyelvtantanításra, nem megfelelően mérnek és értékelnek (v.ö.: Jánk, 2017, 2018), illetve a retorikus írást tanítják (Pintér és Molnár, 2017). Szilassy (2014) egy vizsgálatában kimutatta, hogy a felsőoktatási tanulmányaikat kezdő, érettségizett diákok szövegalkotási képességeiben nagy hiányosságok vannak. Ennek pedig az az oka, hogy a közoktatásban nincs kellő hangsúly fektetve a diákok írásbeli szövegalkotásának fejlesztésére. Mindezek ellenére a felsőoktatásban elvárás, hogy a hallgatók tudományos íráskészsége megfelelő legyen ahhoz, hogy képesek legyen egy jó felépített, tudományosan megfogalmazott szöveget leadni. A hallgatók tudományos 
1ráskészségének fejlesztésére alakult ki a nemzetközi szakirodalomban academic writing-ként elterjedt tudományos szövegszerkesztésre épülő kurzus, melynek alapján a tudományos és az akadémiai írás alkotják. A tudományos írás (scientific writing) és az akadémiai írás (academic writing) a források felhasználására épül. Ezek főleg a tudományos életben, valamint a felsőoktatásban alkalmazott szövegalkotási formák. A tudományos írás egy kutatási eredményeket ismertető írásforma, amelynek a lényege, hogy tudományos tájékoztatást adjon az olvasónak (Sternberg és Sternberg, 2010). Akadémiai írásnak azt nevezzük, amikor a szerző az adott terület szakirodalmát tanulmányozza, illetve ezzel kapcsolatosan új gondolatokat vet fel (Kruse, 2003). Bár a két fogalmat a szakirodalom gyakran használja szinonimaként, Pintér és Molnár megállapította, hogy „az oktatásban akadémiai írásról beszélünk, amikor tanulási helyzetekben a közös tudásalkotás elsajátítása a cél; ez szemináriumi dolgozatok írásán keresztül gyakorolható és fejleszthető. Ezek folyamatos alkalmazása elvezethet a tudományos íráshoz, ami professzionális szintű tevékenység" (Pintér és Molnár, 2017, 31. o.).

\section{Az IPOO tanulási modell}

Az IPOO egy olyan tanulási modell, melynek neve az Input, Process, Output és Organization szavakból álló mozaikszó. A modell Mező Ferenc és Mező Katalin (2007) nevéhez fűződik, akik a tanulást információ-feldolgozásként értelme- zik. Ez alapján a tanulásnak az négy fó fázisát különbözetjük meg, melyek a következők:

a) input: az információ gyűjtése (bemenet);

b) process: az információ feldolgozása (feldolgozás);

c) output: az információ felhasználása (kimenet);

d) organization: a tanulási folyamat szervezése, irányítása (Mező és Mezô 2007).

Vagyis, az input fázisában jelenlévő új ismeretek feldolgozásra kerülnek a process során, majd az output szakaszában már kiáramló ismeretekként jelennek meg. Lényeges viszont megemlíteni, hogy az egész folyamatot az információ irányítása, szervezése, vagyis az organization követi nyomon, ugyanis hiába a megfelelő minőségű bemenet, ha nincs az egész folyamat jól megszervezve.

Ez alapján a tanulás lehet:

1. Input $>$ Output (improduktív tanulás): információvesztő tanulásról van szó;

2. Input $=$ Output (reproduktív tanulás): megértés nélküli tanulás, amikor a diák ugyanannyi információt ad vissza, mint amennyit kapott;

3. Input < Output (produktív tanulás): információt termelő tanulás: ez esetben a tanuló többet tud a tanulási folyamat végén, mint amennyi információt kapott (Mező és Mező 2007).

A tudományos stílusú és célú szövegalkotás sajátossága, hogy egy elkészült tanulmányt, művet olyan outputnak tekinthetünk, amely inputként szolgál mások 
(olvasók, köztük: opponensek, szakmai közösség, tanítványok) számára, akik legnagyobb tömegben és legvalószínúbb módon a szöveg címével találkoznak legelőször.

\section{Problémafelvetés és hipotézisek}

Jelen kutatás a tudományos szövegalkotás szerves részét képező címadás problematikájára irányul. Manapság kevés kutatás fókuszál arra, hogy a hallgatók milyen tudományos szövegalkotási stratégiákat alkalmaznak egy-egy tudományos munka megírása során. Többek között ezért is tartottuk fontosnak a téma vizsgálatát. A kutatás megkezdése előtt az a hipotézis fogalmazódott meg, hogy a hallgatók a címadás során elmozdulnak a tudományos stílustól a média, a reklám, s elsősorban a figyelem megragadására szolgáló nyelvezet felé.

$\mathrm{Az}$ alábbiakban ismertetésre kerül a vizsgálat során alkalmazott mintaválasztás, módszer, illetve az összegyúlt adatok rendszerezése, ismertetése. Végül, felvázolunk egy olyan tudományos szövegalkotás jellegű, IPOO-modellre épülő kurzust, amely nagy segítség lehet a hallgatóknak a tudományos munkáik megírásakor.

\section{Minta}

A vizsgálatban egyetemi hallgatók és oktatók vettek részt. A teljes minta száma 107, ebből 96 személy (89,7\%) tanár szakos hallgató és 11 személy (10,3\%) oktató. A minta ugyan nem tekinthető reprezentatívnak, ám így is jelzés értékű ered- ményekkel szolgálhat egy későbbi nagyobb mintavétellel történő kutatáshoz. Az adatközlők szakterületen való eloszlása a következőképpen oszlik meg: 67\% bölcsészettudomány, 24,5\% természettudomány, 3,6\% pedagógia, 2,8\% múvészettudomány, 2,8\% társadalomtudomány, 0,9\% hittudomány. A hallgatók 87,7\%-ára jellemző, hogy tudományos munkáik száma 0-3 közé esik. A vizsgálatba az egri Eszterházy Károly Egyetem tanár szakos hallgatói és oktatói kerültek be. A minta kiválasztása kényelmi mintaválasztási módszerrel történt.

\section{Módszer}

Az adatok gyűjtése során a kérdőíves módszer került alkalmazásra. A kérdőív két fő részből állt: az első egy anonim háttérkérdőív volt, míg a második részben az adatközlőknek két absztrakthoz kellett címet és kulcsszavakat rendelniük (lásd: 1. melléklet). Az instrukció nem szabta meg, hogy milyen hosszúnak kell a címnek lennie, illetve, hogy hány kulcsszót írjanak az adatközlők.

Az absztraktok a 2018 tavaszán lezajlott Tudománykommunikáció konferencia absztraktfüzetéből lettek kiválasztva. Az egyik egy csillagászati hírportál működéséről, míg a másik egy természettudományokat népszerűsítő csoportról szól. Lényegesnek tartottuk, hogy a kivonatok ne tartalmazzanak szakkifejezéseket, ugyanis az adatközlőknek ez nehezít(h)ette volna a munkáját.

A kérdőíveket online csupán az oktatók töltötték ki, a hallgatók nyomtatott pél- 
dányt kaptak. Ez a kutatás szempontjából azért volt előnyös, mert így megfigyelhető, hogy egy-egy cím milyen alakulási folyamaton ment át, mire a hallgatók véglegesítették azt.

\section{Eredmények}

A címekben alkalmazott szavak száma átlagosan 2,77 (szórás $=1,27$ ), a medián $=$ 3 szó, a módusz $=2$ szó $(25$. percentilis $=$ 2, 75 pecentilis $=3$ ). Minimum 1 , maximum 8 szóból álltak a címek. Gyakorisági eloszlásukat az 1. táblázat foglalja össze (lásd még: 1. ábra).

1. ábra: a cimekben használt szavak számának eloszlása. Forrás: a Szerző

\begin{tabular}{|c|c|c|c|}
\hline $\begin{array}{c}\text { Címben } \\
\text { használt } \\
\text { szavak } \\
\text { száma }\end{array}$ & $\begin{array}{c}\text { Gyakori- } \\
\text { ság } \\
\text { (db) }\end{array}$ & $\begin{array}{c}\text { Relatív } \\
\text { gyakoriság } \\
(\%)\end{array}$ & $\begin{array}{c}\text { Kumulatív } \\
\text { gyakoriság } \\
(\%)\end{array}$ \\
\hline 1 & 13 & 12,0 & 12,0 \\
\hline 2 & 38 & 35,2 & 47,2 \\
\hline 3 & 32 & 29,6 & 76,9 \\
\hline 4 & 17 & 15,7 & 92,6 \\
\hline 5 & 5 & 4,6 & 97,2 \\
\hline 6 & 1 & 0,9 & 98,1 \\
\hline 7 & 1 & 0,9 & 99,1 \\
\hline 8 & 1 & 0,9 & 100,0 \\
\hline Összesen & 108 & 100,0 & \\
\hline
\end{tabular}

A címek terjedelmét tekintve nem voltak jelentős eltérések az oktatók és a hallgatók címei között, így az adatokat összesítve láthatók az alábbiakban (lásd: 1. ábra). Az adatközlők jellemzően egy-, két-, három-, illetve négyszavas címeket adtak az absztrak(ok)nak. Ha figyelembe veszszük, hogy mennyi lényeges elemet kellene egy jó címnek tartalmaznia, akkor arra következtethetünk, hogy ezek nem feltétlen témamegjelölő címek.

1. ábra: A csillagászat.bu birportálhoz kapcsolódó absztrakt címeinek hossza (forrás: a Szerzó)

\section{Csillagászat.hu}

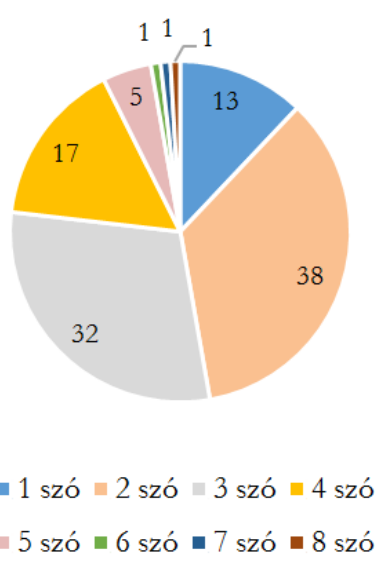

A címek funkciók szerinti csoportosításakor az elméleti részben felvázolt rendszerezést vesszük alapul, mely szerint a legáltalánosabb címtípusok a következők: témamegjelölő cím, címkeszerepú cím, reklámszerepű cím, műfajjelölő cím.

A témamegjelölō címbôl a szöveg tartalma azonnal kiderül. Mivel ezek a címek adnak a legtöbb információt a szövegról, így ez a címtípus van a legközelebb az informativitáshoz. Ebbe a csoportba sorolhatók be a következő címeket: Egy csillagászati hírportál múködéséről, Csillagok, hírek, 
sajtó, Csillagászati hírportál, Csillagászati cikkek, Csilagászati portál, Csillagászati tanulmányok webhelye.

Müfajjelölō címek: A Magyar Csillagászati Egyesület előadása, Felkeltő írás, Csillagászati hírportál ismertetője. Címkeszerepú címek azok, melyek rövidek, és erőteljesen hangulatkeltőek: Csillagászok, Csillagászat, Hírhullás, Tudománynépszerűsítés, Tehetséggondozás, Természetközelben, Tudóspalánták. Ezekre a címekre már kevésbé jellemző az informativitás.

A legkevésbé informatív jellegűek a reklámszerepü címek, amik esetében a figyelemfelkeltésnek nagyobb a szerepe, mint a szöveg tartalmára való utalásnak. Ilyen funkciójú címek a: LOVE TT! (T'T = természettudományok) - ebben az esetben a hallgató az angol nyelvet, és a rövidítést használta figyelemfelkeltésként; CsillagÁsz, TUDOM(ány) - ezekre a címekre a nyelvvel való játékosság jellemző; Életrevalók, Csillag születik, Interstellar már meglévô, más műfajbeli címek alkalmazása. Az adatokból világosan megfigyelhető, hogy a hallgatók körében inkább a bulvárhoz közelítő címek állnak közelebb, még akkor is, ha egy tudományos jellegű szövegről van szó.

Amint korábban is említésre került, nagy jelentősége volt annak, hogy a hallgatók a kérdőív nyomtatott verzióját kapták, ugyanis a válaszaikon látszik a címek alakulásának folyamata. Ez a következôképpen néz ki:

a) A Magyar Csillagászati Egyesület hírportáljáról $\rightarrow$ Hírhullás b) Természet és tudomány $\rightarrow$ Tanulás a természetről $\rightarrow$ Tanító természet

Az a) példa esetében az eredeti cím „A Magyar Csillagászati Egyesület hírtportáljáról" teljesen informatív jellegű volt, amit a hallgató az áthúzás után egy figyelemfelkeltő, címkeszerepű „Hírhullás”-ra alakított. Ezen a példán is megfigyelhető, hogy bár felvetődik egy tudományos verzió, de a hallgatók végül hatásosabbnak ítélik meg a figyelemfelkeltő címet, és úgy döntenek, hogy azt hagyják meg véglegesnek.

A b) példán szintén megfigyelhető a diskurzushibridizáció, ahol a hallgató mindvégig figyelt arra, hogy a címben szerepeljen alliteráció, ám a legelső, sokkal informatívabb címből a végén egy könynyedebb, kevésbé témamegjelölő cím lett.

\section{Megvitatás}

A kutatás megkezdése előtt feltételeztük, hogy a hallgatók a címadás során elmozdulnak a tudományos nyelvhasználattól a sajtó nyelvezete felé. Ezt a feltételezést az összegyűjtött adatok igazolják. Megfigyelhető, hogy hallgatók címadása során jellemzőbb a reklámszerepű, figyelemfelkeltő cím, a témamegjelölő, tudományos nyelvezetû címek viszont már kevésbé gyakoriak. Úgy gondoljuk, hogy annak az adatnak, miszerint a hallgatók $87,7 \%$ nem, vagy nagyon kevés (0-3) tudományos munkát írt, köze van a címadás során megjelenő diskurzushidridizációhoz. A reklámszerepú címekkel ugyanis nap mint találkoznak, szinte mindenhol, így ennek nagyobb a hatása, mint a tudo- 
mányos szövegeknek. Ez pedig meglátszik az absztraktokhoz rendelt címeken is.

\section{Az eredmények hasznosítása:}

\section{javaslat egy IPOO-modellre épülő \\ tudományos szövegalkotást célzó \\ kurzus bevezetésére}

Az adatok kimutatják, hogy az egyetemi hallgatóknak nagyon kevés tudományos írással kapcsolatos tapasztalatuk van. Mindamellett elvárás, hogy tudományosan megszerkesztett munkát adjanak le tanulmányaik során (beadandó, tanulmány), vagy tanulmányaik befejeztével (szakdolgozat). Éppen ezért mindenképpen nagy hasznukra válna egy tudományos írást bemutató, elősegítő kurzus, ahol betekintést nyernének a tudományos szövegek világába.

Az IPOO-modellnek - melyre alapozható a tudományos szövegalkotás kurzus négy fő összetevője van: Input, Process, Output, Organization.

Az Input fázis során a hallgatókat megismertetjük a tudományos írás alapjaival. Bemutatjuk nekik a tudományos műfajokat (például: tanulmány, tudományos értekezés, tudományos esszé, stb.), illetve olyan kritériumokat tanítunk meg, amelyek fejlesztik a hallatók tudományos íráskészségét. Ilyen kritériumok például a:

- címadás: terjedelem, funkció;

- forrás: a megfelelő szakirodalom kiválasztása;

- hivatkozás, idézés.

Az Input részben nagyon sokféle cím-, szövegtípus tanítására, gyakoroltatására van szükség, hogy az új ismeretek megfelelően megszilárduljanak. Olyan feladattípusok tanítására gondolunk, mint az alábbi két mintafeladat:

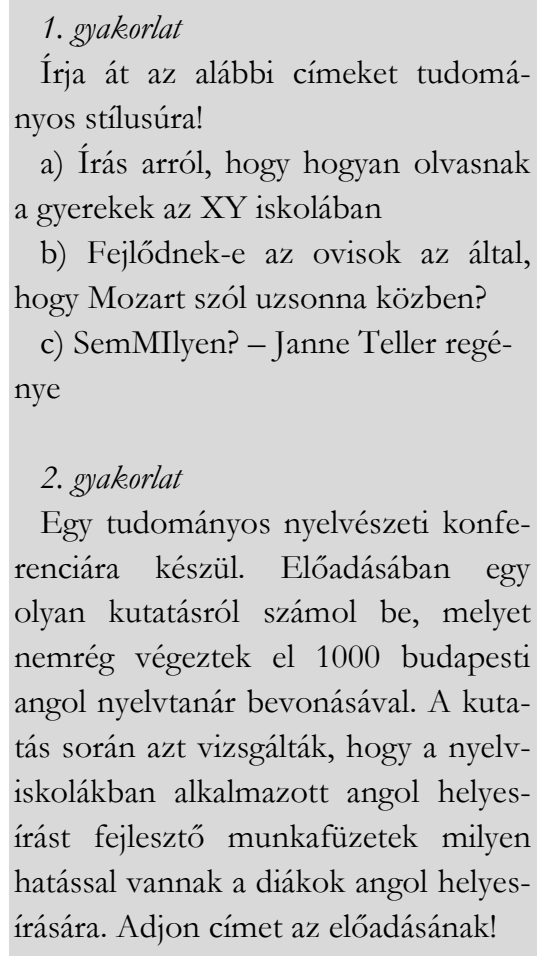

a) Írás arról, hogy hogyan olvasnak a gyerekek az XY iskolában

b) Fejlődnek-e az ovisok az által, hogy Mozart szól uzsonna közben?

c) SemMIlyen? - Janne Teller regénye

2. gyakorlat

Egy tudományos nyelvészeti konferenciára készül. Előadásában egy olyan kutatásról számol be, melyet nemrég végeztek el 1000 budapesti angol nyelvtanár bevonásával. A kutatás során azt vizsgálták, hogy a nyelviskolákban alkalmazott angol helyesírást fejlesztő munkafüzetek milyen hatással vannak a diákok angol helyesírására. Adjon címet az előadásának!

A Process fázisában ez az információmennyiség feldolgozásra kerül, és az Outputban lesz majd megfigyelhetô a hatása. Ahhoz, hogy a hallgatók el tudják sajátítani a tudományos szövegalkotást, nagyon sok Inputra, információra van szükség. A kurzus Output részében a hallgatóknak egy tanulmányt kell majd írniuk az előre megadott témára, amin azt figyeljük majd, hogy alkalmazták-e a kurzus során elsajá- 
tított információt. Az Organization olyan munkaformákat takar, amely során a hallgatók mélyebben sajátítják el az ismeretanyagot. Ide tartozik például a páros munka, amikor egymás tanulmányait javítják ki, egymás tanulmányain keresztül hívják fel egymás figyelmét az írás során elkövetett hibákra. Az Organization részbe soroljuk az egyéni munkát is, amikor a hallgatók önállóan dolgoznak egy-egy szövegen. Végül, az utolsó komponenshez tartozik az is, hogy az egész kurzus egyetemi hallgatók képzésébe illeszkedik bele, és egy szemeszteren keresztül tart. Lényeges, hogy a hallgatók írjanak egy szöveget a kurzus elején és a kurzus végén is, amiket összehasonlítva megfigyelhetőek majd, hogy melyek azok a területek, amelyekben történet előrehaladás, és melyek azok, ahol nem.

\section{Korlátozások}

Mivel jelen kutatásban nem beszélhetünk reprezentatív mintáról, a jövőben szükséges a hallgatói és oktatói sokaságot jól képviselő mintán is megfigyelni a tudományos múvekre vonatkozó címadási stratégiákat. Feltételezzük, hogy az oktatók esetében is jelen van a diskurzushibridizáció. E hipotézisnek az az alapja, hogy a jelenlegi kutatásban is volt arra példa, amikor egy oktató olyan címet (Lájk a természettudományokra!) adott az absztraktnak, amely egyértelműen e jelenség jelenlétére utal. Jelen empirikus kutatás eredményei azt is mutatják, hogy a hallgatók tudományos szövegalkotó képessége (és olvasottsága!) nem megfelelő, így a terveink között szerepel az is, hogy megvizsgáljuk azt, hogy az IPOO-modellre épülő kurzus változtat-e ezen.

\section{Konklúziók}

A kutatás során összegyűjtött adatokból egyértelműen kiolvasható, hogy a hallgatók által a tudományos szövegeknek adott címekben jelen van a diskurzushibridizáció. A kutatás során használt kérdőívben két tudományos szövegnek (absztraktnak) kellett címet adniuk. Az adatok azt mutatják, hogy a hallgatók nagyobb gyakorisággal adnak figyelemfelkeltő, reklámszerepű címet, mint tudományos stílusút. Úgy tûnik ugyanakkor, hogy a diskurzushibridizáció, vagyis a tudományos hangnem elmozdulása a sajtó nyelvezete felé az oktatók között is elterjedőben van.

Az eredményekből kiolvasható azt is, hogy a tanár szakos hallgatóknak nagyon kevés tudományos írással kapcsolatos tapasztalatuk van, ezért mindenképpen megfontolandó, hogy egy IPOO-modellre épülő, tudományos szövegalkotás jellegű kurzus bekerüljön a hallgatók képzési programjába.

\section{Irodalom}

Al-Khasawneh, F. M. (2017): A Genre Analysis of Research Article Abstracts Written by Native and Non-Native Speakers of English. Journal of Applied Linguistics and Language Research, 2017, Vol. 4, Issue 1, pp. 1-13 
Cross, C. \& Oppenheim, Ch. (2006): A genre analysis of scientific abstracts. Journal of Documentation, 2006, Vol. 62, Issue: 4, pp. 428-446

Day, A. R. (1995): How to write \& publish a scientific paper? 4th edition. Canada: Cambridge University Press.

Domonkosi, Á. (2016): A metonimikusság szerepe a sajtónyelvi címadásban. In Reményi A. Á., Sárdi Cs. és Tóth Zs. (szerk.): Távlatok a mai magyar alkalmazott nyelvészetben. Tinta Könyvkiadó, Budapest. 503-509.

Fairclough, N. (1992): Discourse and Social Change. Cambridge: Polity Press.

Fairclough, N. (1993): Critical discourse analysis and the marketisation of public discourse: the universities. Discourse and Society, 1993, 4, 133-168.

Falus, I. (2004): Bevezetés a pedagógiai kutatás módszereibe. Műszaki Könyvkiadó, Budapest.

Jánk, I (2017): Nyelvi hátrány és diszkrimináció az iskolában. A nyelvi szocializáció jelentősége a tanuló értékelésében. Szociológiai Szemle, 27(3), 27-47.

Jánk, I. (2018): Nyelvi disækerimináció és nyelvi elöitéletesség a pedagógiai értékelésben: Négy ország gyakorló és leendō magyartanárainak. körében végzett kutatás eredményei (disszertáció). Nyitra.

Kemény, G. (1985): Kép és kommunikáció. In Grétsy L. (szerk.): Nyelvészet és tömegkommunikáció II. Tömegkommunikációs Kutatóközpont, Budapest, 119-205.

Kruse, O. (2003): Getting started: academic writing in the first year of a university education. In Björk, L, Bräuer, G., Rienecker, 1. \& Jörgensen, P. S. (Eds.): Teaching academic writing in European higher education. Dordrecht: Kluwer Academic Publishers.

Mező F. és Mező K. (2007): Tanulási stratégiák fejlesztése az. IPOO-modell alapján (Második, átdolgozott kiadás). Tehetségvadász Stúdió - Kocka Kör Tehetséggondozó Kulturális Egyesület, Debrecen.

Pintér, H. és Molnár, P. (2017). A forrásokra építő tanuláscélú írás: a forrásalapú írás. Magyar Pedagógia. 117/1. 29-48.

Rodrigues, V. (2013): How to write an effective title and abstract and choose appropriate keywords. Letöltés: 2018. 11. 22. Web: https://www.editage.com/ insights/how-to-write-an-effectivetitle-and-abstract-and-choose-appro priate-keywords

Sternberg, R. J. \& Sternberg, K. (2010): The psychologist's companion: A guide to writing scientific papers for students and researchers. New York, NY: Cambridge University Press.

Szikszainé, N. I. (1999): Leíró magyar szövegtan. Budapest: Osiris Kiadó.

Szilassy, E. (2014). Egy felsőoktatási szövegalkotási felmérés tanulságai. Anyanyelv-pedagógia, 7(3). Letöltés: 2019. 01.03. Web: http://www.anyanyelvpedagogia.hu/cikkek.php?id=528 doi 10.17670/MPed.2017.1.29

Talebzadeh, H., Samar, R. G., Kiany, G. R. \& Akbari, R. (2013): Steps to a Successful Abstract: A Comparative Genre Analysis. Intl. J. Humanities (2013) Vol. 20 (3), 1-25. pp 
Tolcsvai, N. G. (2001): A magyar nyelv szövegtana. Budapest: Nemzeti Tankönyvkiadó.

Tomesz, T. (2009): Címek a bulvárban. In A médianyelv bulvárosodása. Acta Academiae Paedagogicae Agriensis. Sectio Communicationis. 2009. 28-39.

Tomesz, T. (2015): A TARTALOMHOZ FOR MA. A tömegkommunikáció szövegfajtái történeti és pragmatikai keretben. Liceum Kiadó, Eger.
Veszelszki, Á. (2016): Academic Writing, wissenschaftliches Schreiben, tudományos írás. Egyetemi hallgatók írásos produktumai - stilisztikai és grammatikai szempontból. In: Feld-Knapp, I. (szerk.): Grammatik. Cathedra Magistrorum 3. Eötvös-József-Collegium, Budapest. 286-305.

Veszelszki, Á. (2018) „Konkrétan az absztraktról”. In Veszelszki Á. és Cser N. (szerk.): Tudománykommunikáció konferencia: absztraktkötet. Budapesti Corvinus Egyetem Magatartástudományi és Kommunikációelméleti Intézet, Budapest. 29. 


\section{Melléklet:}

„A cím és a kulcsszó szerepe a tudományos szövegekben" kérdőív

\section{Kedves Adatközlö!!}

Jelen kérdőív a cím és a kulcsszavak szerepét vizsgálja a tudományos szövegeken belül. A kérdőívben két absztrakt (egy előadás/tanulmány kivonata, összefoglalója) szerepel, melyekkel kapcsolatosak a kérdések.

Kérem, figyelmesen olvassa el az utasításokat, majd ennek függvényében töltse ki a válaszadó mezőket. A kérdőív kitöltése körülbelül 5-10 percet vesz igénybe.

Köszönöm a segítségét!

Neme: férfi nő

Státusæ: hallgató oktató

Évfolyam: 1. 2. 3. 4. 5.

\section{Tudományterület:}

Bölcsészettudományok

Hittudományok

Műszaki tudományok

Müvészetek

Orvostudományok

Társadalomtudományok

Természettudományok

Szak/sqakterïlet: ...

Tudományos munkák száma: $\begin{array}{llll}0-3 & 4-9 & 10-29 & 30+\end{array}$

Kérem, olvassa el az alábbi abs zৃtraktot!
Közel másfél évtizede indítottuk a www.csillagaszat.hu híroldalt a tudós szakma és a kapcsolódó civil szféra együttműködésében. A Magyar Csillagászati Egyesület hírportáljaként működő oldalon egyetemi és akadémiai oktatók, kutatók, kisebb arányban egyetemi hallgatók írásai jelennek meg, jellemzően heti 45 csillagászati cikk formájában. Az előadásban bemutatjuk a hosszú távú működést lehetővé tevő legfontosabb tényezőket, a tapasztalatokat a sajtóval való együttműködés lehetőségeiről, illetve bátorítjuk más szaktudományok képviselőit hasonló kezdeményezések elindítására.

Kérem, adjon címet az absztraktnak!

Kérem, jelöliön meg kulcsszavakat az adott elóadás témájához!

\section{Kérem, olvassa el az alábbi abs ztraktot!}

Mit tehet egy 21 éves fiatal azért, hogy nála alig néhány évvel fiatalabb társai jobban szeressék a természettudományokat? Hogyan taníthatja meg a 10-16 éves gyerekeket, hogy mit higgyenek el, és mit ne; honnan ismerhetik fel, ha valami áltudomány, és honnan, ha valami valódi tudomány? Hogyan lett egy kezdeti, „természettudományokat fogok népszerűsíteni nagykoromban" álomból valóság? Előadásomban szeretnék választ adni e kérdésekre; bemutatni, hogyan alakult ki tudománynépszerűsítő csapatunk (tupim. ga), illetve felvázolom azokat az innovatív megoldásokat, amelyekkel népszerüsítjük a természettudományokat. Tudománynépszerűsítő munkám mellett nagy hang- 
súlyt fektetek arra is, hogy a fiatal korosztállyal megismertessem azokat a problémaköröket, melyekről az iskolában nem vagy csak keveset hallanak, mégis mire felnőnek égetô kérdések lesznek (pl. robotok jogairól szóló kérdések, energia előállításának kérdése stb.). Előadásom- ban ismertetem, milyen módszerekkel lehet fejleszteni a diákok soft-skilljeit, hogy készen álljanak ezen kérdések megválaszolására.

Kérem, adjon címet az absztraktnak!

Kérem, jelöljön meg kulcssqavakat az adott elöadás témájáhor! 